\title{
FREQUENCY, URINALYSIS AND SUSCEPTIBILITY PROFILE OF PATHOGENS CAUSING URINARY TRACT INFECTIONS IN ENUGU STATE, SOUTHEAST NIGERIA
}

\author{
Uju M.E. DIBUA(1), Ifeoma S. ONYEMERELA(1) \& Emeka I. NWEZE(1)
}

\begin{abstract}
SUMMARY
Objective: This study was designed to determine the frequency and causative agent(s) of urinary tract infections (UTIs) in individuals with symptoms of urinary tract infections in Enugu State of Southeast Nigeria, and to determine the antibiotic susceptibility pattern of microbial agents isolated from urine culture. Methods: The study involved 211 individuals (149 females and 62 males) clinically suspected for UTI. Urine samples were collected by the mid-stream 'clean catch' method and tested using standard procedures. Antibiotic susceptibility of the isolated pathogens was tested using the Kirby-Bauer technique according to the Clinical and Laboratory Standards Institute (CLSI) guidelines. Results: Microscopy of centrifuged urine samples showed 16 patients had pyuria while 54 had pus cells. Calcium oxalate crystals were found in 14 samples. Urinalysis performed with urine samples showed 17 had protein; seven were nitrite positive and three had moderate to high glucose concentration. Fifty-four urine samples (36.2\%) from females and 12 (19.4\%) from males showed significant growth upon culture. Gram stain and biochemical tests identified nine different organisms with Escherichia coli as the most common isolated species. Forty three randomly selected strains were further tested for their susceptibility against a panel of antibiotics. Thirty isolates $(81.08 \%)$ were resistant to four or more antibiotics with the highest resistance shown by E. coli $(76.67 \%)$. All the Gram- negative isolates were resistant to Ampicilox, Cefuroxime and Amoxicillin. Conclusion: Urinary tract infections were found more in females in the area under study. As found in other studies, E. coli was the most predominant isolate, although other organisms seem to be on the increase.
\end{abstract}

KEYWORDS: Urinary tract infection; Pathogen; Southeast Nigeria; Etiology; Antibiotic susceptibility.

\section{INTRODUCTION}

Urinary tract infections (UTIs) are among the most common infections diagnosed in both hospitalized and outpatients ${ }^{12}$. About 150 million UTIs are reported worldwide every year ${ }^{9}$ costing the world economy over six billion US dollars ${ }^{2}$. UTIs are reportedly the most common bacterial infections in women and account for significant morbidity and increase in the cost of healthcare. In young sexually active women, the incidence of UTI exceeds 0.5 episodes per year with about $30 \%$ of women experiencing recurrent infections. In developed countries such as the USA, UTIs alone account for over eight million physician visits per year? ${ }^{7}$. In developing countries, especially in many resource poor settings, the situation is worse and many clinicians often initiate empiric antibiotic treatment even before the final laboratory diagnostic test results are available. This is occasioned by the long duration, high cost and non-availability of experienced personnel and equipment needed for reporting accurate diagnosis by culture and susceptibility testing. Currently, there is an increasing problem of resistance to antibiotics especially in developing countries, prompting the need for a good knowledge of antibiotic resistance patterns of these pathogens so as to ensure efficient treatment and eradication. Moreover, area-specific studies are required in monitoring the trend and gaining useful knowledge about the type of pathogens responsible for UTIs. The etiology and resistance patterns of community- acquired UTI pathogens have not been studied extensively in many settings ${ }^{8}$. Moreover, even in areas where a few studies have been done, there is need to continue to monitor the trend in terms of the etiology and antibiotic resistance patterns of these uropathogens. Although a few studies have been carried out previously in Southeast Nigeria $^{5,6,14}$, most of them investigated UTIs in association with other diseases in certain specific populations. Thus, there is not much recent data specifically on the etiology and antimicrobial resistance patterns of uropathogens among individuals specifically presenting with UTIs in Enugu State, Southeast Nigeria. This information will be very useful to clinicians so as to facilitate empirical treatment and management of patients with symptoms of UTIs. We therefore carried out this study to ascertain the current etiology and antimicrobial susceptibility patterns of uropathogens in Enugu State, Nigeria.

\section{MATERIALS AND METHODS}

Sample collection and analysis: Urine samples were collected from three randomly selected centers: Bishop Shanahan Hospital, Nsukka, 


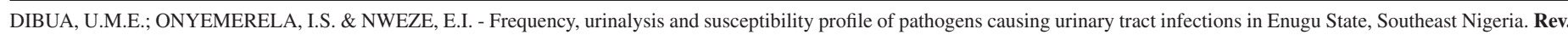
Inst. Med. Trop. Sao Paulo, 56(1): 55-9, 2014.

McChuks Medical Diagnostic Laboratory, Enugu and Dynamic Medical Diagnostic Laboratory, Enugu all located in Enugu State, Southeast Nigeria. The patients who came for consultation and whose urine samples were collected were all outpatients. They were given sterile wide-mouthed containers and instructed on how to collect clean, mid-stream, voided urine samples. Those who were unable to collect their own samples were aided. Consent approvals were obtained from all those who participated in the study. The study was approved in each center where samples were collected. Patients who had no symptoms suggestive of UTI at the time of observation were excluded from the study. Those suffering from diabetes mellitus, renal disorders, HIV positivity or on corticosteroid or antibiotic therapy were also excluded. Those who refused to give consent or were non-cooperative were not included in the study.

Urinalysis: The urine samples were examined macroscopically for color and turbidity. They were then centrifuged and the sediment examined microscopically for the presence of red blood cells, white blood cells (pus cells), protozoa, Schistosoma eggs, yeasts and crystals. They were inspected for $\mathrm{pH}$ and the presence of glucose, protein and nitrite using Combi 9 (Medi-Test, Machery-Nagel GmbH, Duren) dipstick.

Isolation and identification of bacterial isolates from urine samples: A loopful of each fresh urine sample was inoculated onto Cysteine Lactose Electrolyte-Deficient (CLED) agar (Oxoid, UK) and incubated for $18-24 \mathrm{hrs}$ at $37^{\circ} \mathrm{C}$. Urine samples, that had yeast cells upon microscopic examination, were inoculated onto Sabouraud Dextrose Agar (SDA) (Oxoid, UK) and incubated at $37^{\circ} \mathrm{C}$ for $18-24 \mathrm{~h}$. Discrete colonies were placed in slants and kept in the refrigerator and characterized as previously described ${ }^{4}$.

Antibiotic Susceptibility Test: Sterile Mueller-Hinton Agar plates were seeded with $0.1 \mathrm{~mL}$ of 0.5 MacFarland (approximately $10^{7} \mathrm{CFU} /$ $\mathrm{mL}$ ) standardized isolates, spread out with a bent sterile glass rod and left to dry on the bench for 30 minutes. Antibiotic discs were placed aseptically on the plates using sterile forceps. Plates were then incubated at $37{ }^{\circ} \mathrm{C}$ for $16-18 \mathrm{~h}$. The diameters of the zones of inhibitions were measured, recorded and interpreted according to CLSI approved standard guidelines ${ }^{13}$. The antibiotics tested against Gram positive organisms were Septrin $(30 \mu \mathrm{g})$, Erythromycin $(10 \mu \mathrm{g})$, Pefloxacin $(10 \mu \mathrm{g})$, Gentamycin $(10 \mu \mathrm{g})$, Ampiclox $(30 \mu \mathrm{g})$, Zinnacef $(20 \mu \mathrm{g})$, Amoxacillin $(30 \mu \mathrm{g})$, Rocephin $(30 \mu \mathrm{g})$ and Ciprofloxacin $(10 \mu \mathrm{g})$ while those tested against Gram negative organisms were septrin $(30 \mu \mathrm{g})$, Chloramphenicol (30 $\mu \mathrm{g})$, Sparfloxacin $(10 \mu \mathrm{g})$, Ciprofloxacin $(10 \mu \mathrm{g})$, Amoxacillin $(30 \mu \mathrm{g})$, Augmentin $(30 \mu \mathrm{g})$, Gentamycin $(10 \mu \mathrm{g})$, Pefloxacin $(30 \mu \mathrm{g})$, Tarivid (10 $\mu \mathrm{g})$ and Streptomycin $(30 \mu \mathrm{g})$.

\section{RESULTS}

Isolation and characterization of microbial isolates: A total of 211 urine samples (149 from females, 62 from males) were collected from all three centers located in Enugu State, Nigeria. Microscopy of centrifuged urine samples showed 16 (11 females and five males) had significant number of pus cells (pyuria) while 54 (46 female and eight males) had fewer pus cells. Calcium oxalate crystals were found in 14 urine samples (four with growth and 10 without growth). One male urine sample contained tyrosine crystals; another contained cysteine crystals with microbial growth on inoculation, while another had Schistosoma eggs and a lot of red blood cells. One female urine sample had triple phosphate crystals (with no microbial growth); and another seven had numerous epithelial cells, also without any growth. Urinalysis carried out with combi-9 (Medi-Test) showed 17 urine samples (10 with growth and seven without growth) had protein; seven urine samples (all with growth) were nitrite positive and three urine samples had moderate to high glucose concentration. Fifty-four urine samples (36.2\%) from females and twelve urine samples $(19.4 \%)$ from males showed significant growth. The isolates were identified using Gram stain and biochemical tests as Escherichia coli (17), Staphylococcus species (12), Staphylococcus aureus (7), Proteus species (8) Pseudomonas aeruginosa (6), Candida species (7), Enterobacter species (5), Klebsiella species (3), and Candida albicans (2).

From the above isolates, 43 strains - Escherichia coli (12), Staphylococcus species (10), Proteus species (5), Staphylococcus aureus (4), Candida species (4), Klebsiella species (3), Pseudomonas aeruginosa (3), and Candida albicans (2) were used for the study.

Antibiotic susceptibility profile of the recovered urine isolates: Out of the 43 clinical bacterial isolates used in the study, 30 (81.08\%) were resistant to four or more antibiotics with the highest resistance shown by E. coli (76.67\%), followed by Klebsiella species (63.33\%), S. aureus (57.5\%), Pseudomonas aeruginosa (53.33\%), Staphylococcus species (51\%), and the least was Proteus species (38\%). All the Gram-negative isolates were resistant to Ampiclox, Cefuroxime and Amoxacillin. However, most isolates were less resistant to Ciprofloxacin and it was thus used as the antibiotic control (Tables 1 and 2).

\section{DISCUSSION}

Microscopy of the centrifuged urine samples showed presence of moderate to many pus cells (white blood cells) in fewer urine samples which showed significant microbial growth on culture; presence of crystals such as calcium oxalates, tyrosine, cystine and triple phosphate; epithelial cells and Schistosoma eggs with numerous red blood cells. Pyuria, which is the presence of pus cells in this quantity, is an indication of microbial infections since pus cells are white blood cells that have succumbed in defense of the body against pathogens that invade it. Few are singly excreted in normal urine but in clumps in urinary infections. Pyuria with significant microbial growth $\left(\geq 10^{5}\right.$ organisms $\left./ \mathrm{mL}\right)$ in 16 urine samples is a good indication of urinary tract infection while significant microbial growth (bacteriuria) without pyuria in 54 urine samples screened in this study may be an indication of diabetes, enteric fever, bacterial endocarditis or contaminants from the perineum.

Crystals are formed from chemicals in normal urine and are usually refractive in appearance. The crystal types found indicate the presence or absence of a disease. Calcium oxalate crystals are formed from oxalic acid abundance in diet rich in leafy vegetables or coffee and calcium excreted into urine due to chronic dehydration or hyperparathyroidism. The crystals usually form stones (calculi) in the kidneys, ureters or bladders. Therefore, the presence of calcium oxalate crystals might be an indication of calculi in the urinary tract, a predisposing factor to urinary tract infection. Tyrosine crystals presence might indicate a possible severe liver disease while cystine crystals are found in cystinuria, a rare congenital metabolic disorder. Presence of numerous epithelial cells may indicate inflammation of the urinary tract or vaginal contamination of the specimen; triple phosphate crystals in urine is not harmful but 


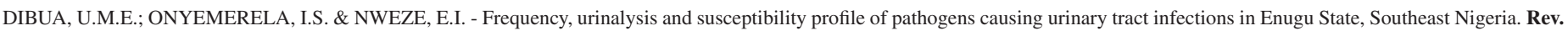
Inst. Med. Trop. Sao Paulo, 56(1): 55-9, 2014.

Table 1

Antibiotic susceptibility test result against Gram - positive UTI isolates

\begin{tabular}{|c|c|c|c|c|c|c|c|c|c|c|c|}
\hline \multirow{2}{*}{ Urine isolates (No.) } & \multicolumn{10}{|c|}{ ANTIBIOTIC TESTED } & \multirow{2}{*}{$\%$ resistance } \\
\hline & $\mathrm{S}$ & SXT & $\mathrm{E}$ & PEF & $\mathrm{CN}$ & APX & $\mathrm{Z}$ & $\mathrm{AM}$ & $\mathrm{R}$ & CPX & \\
\hline S. aureus (1) & + & + & + & + & + & + & + & + & + & - & 90 \\
\hline S. aureus (2) & + & - & - & - & - & + & + & + & - & - & 40 \\
\hline S. aureus (3) & - & + & + & - & $+/-$ & + & + & + & - & - & 60 \\
\hline S. aureus (4) & - & - & + & - & - & + & + & + & - & - & 40 \\
\hline Staphylococcus spp (1) & - & - & + & + & - & + & + & + & + & + & 70 \\
\hline Staphylococcus spp ( 2) & - & - & + & - & - & + & + & + & - & - & 40 \\
\hline Staphylococcus spp (3) & - & - & - & - & - & + & + & + & + & - & 40 \\
\hline Staphylococcus spp (4) & $+/-$ & + & + & - & - & + & + & + & - & - & 60 \\
\hline Staphylococcus spp (5) & + & + & + & + & + & + & + & + & + & - & 90 \\
\hline Staphylococcus spp (6) & - & - & - & - & - & + & + & + & - & - & 30 \\
\hline Staphylococcus spp (7) & + & - & + & - & - & + & + & + & - & - & 50 \\
\hline Staphylococcus spp (8) & - & - & - & - & - & $+/-$ & + & + & - & - & 30 \\
\hline Staphylococcus spp (9) & - & + & + & - & $+/-$ & + & + & + & - & - & 60 \\
\hline Staphylococcus spp (10) & - & - & + & - & - & + & + & + & - & - & 40 \\
\hline Total resistance (\%) & 35.71 & 35.71 & 71.43 & 21.43 & 28.57 & 100 & 100 & 100 & 28.57 & 7.14 & \\
\hline
\end{tabular}

- = susceptible; $+/-=$ intermediate; + = resistant; $\mathrm{sp}=$ species; $\mathrm{S}=$ Septrin $30 \mu \mathrm{g}, \mathrm{E}=$ Erythromycin $10 \mu \mathrm{g}, \mathrm{PEF}=$ Pefloxacin $10 \mu \mathrm{g}, \mathrm{CN}=\mathrm{Gentamycin} 10 \mu \mathrm{g}, \mathrm{APX}=$ Ampiclox $30 \mu \mathrm{g}, \mathrm{Z}=$ Zinnacef $20 \mu \mathrm{g}, \mathrm{AM}=$ Amoxacillin $30 \mu \mathrm{g}, \mathrm{R}=$ Rocephin $30 \mu \mathrm{g}$ and CPX = Ciprofloxacin $10 \mu \mathrm{g}$.

indicates the $\mathrm{pH}$ is highly alkaline while presence of Schistosoma cells and numerous red blood cells indicates the infection, schistosomiasis ${ }^{10,11}$. Urinalysis results showed the presence of protein, nitrite and moderate to high glucose concentration in urine samples. Presence of protein in urine known as proteinuria is usually an indication of kidney disorders including glomerulonephritis and urinary tract infection. Nitrates are found in normal urine and are as a result of feeding on a diet containing vegetables. They are reduced to nitrites by pathogens such as E. coli, Proteus species and Klebsiella species when in sufficient concentration in the urine. On the other hand, presence of glucose in urine is an indication of diabetes mellitus ${ }^{11,19}$. The different urine isolates recovered were Escherichia coli (24. 6\%), Staphylococcus species (17.4\%), Staphylococcus aureus (11.6\%), Proteus species (11.6\%), Pseudomonas aeruginosa (10.1\%), Candida species (10.1\%), Enterobacter species (7.2\%), Klebsiella species $(4.3 \%)$ and Candida albicans $(2.9 \%)$. This agrees with the findings of LAUPLAUD et al. ${ }^{11}$ which gave the percentage of $E$. coli implicated in urine of patients in Calgary Health Region Intensive Care Unit in Canada as $23 \%$. Only $2.9 \%$ of Candida albicans were recovered compared to $20 \%$ found by LAUPLAUD and co-workers ${ }^{11}$ suggesting that they were not nosocomial infections. However, the percentage of E. coli $(24.6 \%)$ disagrees with the findings of AIYEGORO et al. ${ }^{1}$ and ZEIGHAMI $(2008)^{21}$ which were respectively $52.6 \%$ and $55.9 \%$. AIYEGORO et al. $^{1}$ working with out-patients aged 5-18 years visiting Obafemi Awolowo University Teaching Hospital Complex Ile-Ife in Nigeria also isolated Klebsiella spp. (25\%), Proteus spp. (3.9\%) and P. aeruginosa (2.8\%). ZEIGHAMI (2008) $)^{21}$ working with urine of patients that had kidney transplant and asymptomatic bacteriuria also isolated Klebsiella spp. (22.4\%), P. aeruginosa (8.6\%), and Proteus spp. (5.2\%). These organisms have been said to be common cause of nosocomial infections ${ }^{3,4}$. We also isolated these organisms though the percentage of Klebsiella species (4.3\%) was smaller than those reported above. Staphylococcus species and Staphylococcus aureus are normal body flora and must have come from the environment. The fact that more urine samples from females (36.2\%) showed significant microbial growth as against males $(19.4 \%)$ is in line with the findings of AIYEGORO et al. ${ }^{1}$ who reported bacteriuria only in urine from females. KWOK et al. ${ }^{10}$ sampled children aged 0-18 years and showed that UTI in girls was (34.4 episodes/1000 persons) as against males (4.4 episodes/1000 persons) and this agrees with our finding. The nature and proximity of the urinary system and the anus in women may be the reason why women had more bacteria growth in their samples than men since many organisms from feces can easily infect or contaminate the urinary system in females.

The antibiotic susceptibility profile of the urine isolates showed that E. coli (76.7\%), Klebsiella species (63.3\%), S. aureus $(57.5 \%)$, P. aeruginosa (53.3\%), Staphylococcus $(51 \%)$ and Proteus $(38 \%)$ species were resistant (not susceptible) to conventional antibiotics used. BROOKS et al. ${ }^{3}$ stated that antibiotics such as derivatives of penicillin (ampicillin and amoxicillin), sulphonamides, and the quinolones (nitrofurantoin and nalidixic acid) are effective urinary antiseptics. The genera Escherichia, Klebsiella and Pseudomonas from urine show multiple resistances to antibiotics with Klebsiella species and E. coli noted to be resistant to broad-spectrum $\beta$-lactam drugs like penicillins and third generation cephalosporins ${ }^{20}$. All S. aureus, Klebsiella species, $P$. aeruginosa and $83.33 \%$ of $E$. coli in our study were resistant to four or more antibiotics. Among the E. coli, $83.33 \%$ were resistant to septrin 
DIBUA, U.M.E.; ONYEMERELA, I.S. \& NWEZE, E.I. - Frequency, urinalysis and susceptibility profile of pathogens causing urinary tract infections in Enugu State, Southeast Nigeria. Rev. Inst. Med. Trop. Sao Paulo, 56(1): 55-9, 2014.

Table 2

Antibiotic susceptibility test result against Gram - negative UTI isolates

\begin{tabular}{|c|c|c|c|c|c|c|c|c|c|c|c|}
\hline \multirow{2}{*}{ Urine isolates (No.) } & \multicolumn{10}{|c|}{ ANTIBIOTIC TESTED } & \multirow{2}{*}{$\%$ resistance } \\
\hline & SXT & $\mathrm{CH}$ & SP & $\mathrm{CPX}$ & $\mathrm{AM}$ & $\mathrm{AU}$ & $\mathrm{CN}$ & PEF & OFX & $\mathrm{S}$ & \\
\hline E. coli 1 & + & + & + & + & + & + & $+/-$ & + & + & $+/-$ & 100 \\
\hline E. coli 2 & $+/-$ & - & $+/-$ & - & $+/-$ & - & - & - & - & $+/-$ & 40 \\
\hline E. coli 3 & - & - & + & - & - & - & - & - & - & - & 10 \\
\hline E. coli 4 & + & + & + & $+/-$ & + & + & $+/-$ & + & $+/-$ & + & 100 \\
\hline E. coli 5 & + & + & + & + & + & + & - & + & + & + & 90 \\
\hline E. $\operatorname{coli} 6$ & + & + & + & + & + & + & + & + & + & $+/-$ & 100 \\
\hline E. coli 7 & + & + & + & + & + & + & + & + & + & $+/-$ & 100 \\
\hline E. coli 8 & + & + & + & + & + & + & $+/-$ & + & + & $+/-$ & 100 \\
\hline E. coli 9 & - & - & + & + & + & - & - & - & - & - & 30 \\
\hline E. coli 10 & + & + & + & - & - & - & - & $+/-$ & $+/-$ & $+/-$ & 60 \\
\hline E. coli 11 & + & - & + & + & + & + & + & + & + & $+/-$ & 90 \\
\hline E. coli 12 & + & + & + & + & + & + & + & + & + & $+/-$ & 100 \\
\hline Klebsiella spp 1 & + & - & - & - & $+/-$ & + & + & - & - & + & 50 \\
\hline Klebsiella spp 2 & + & + & + & $+/-$ & + & + & $+/-$ & - & - & $+/-$ & 80 \\
\hline Klebsiella spp 3 & + & + & + & - & + & + & - & - & - & + & 60 \\
\hline Proteus spp 1 & - & - & - & - & - & + & - & - & - & - & 10 \\
\hline Proteus spp 2 & + & + & + & - & + & $+/-$ & - & + & + & - & 70 \\
\hline Proteus spp 3 & + & + & + & - & + & + & - & - & - & - & 50 \\
\hline Proteus spp 4 & $+/-$ & + & - & - & - & + & - & - & - & - & 30 \\
\hline Proteus spp 5 & $+/-$ & + & - & - & - & + & - & - & - & - & 30 \\
\hline P. aeruginosa 1 & + & + & + & - & - & + & - & - & - & - & 40 \\
\hline P. aeruginosa 2 & + & + & + & - & - & + & - & - & - & - & 40 \\
\hline P. aeruginosa 3 & + & + & + & + & + & + & - & + & + & - & 80 \\
\hline$\%$ resistance & 87.0 & 73.9 & 82.6 & 47.8 & 69.6 & 82.6 & 39.1 & 47.8 & 47.8 & 56.5 & \\
\hline
\end{tabular}

- = susceptible; + - = intermediate; + = resistant; spp = species, $\mathrm{SXT}=30 \mu \mathrm{g}$ septrin $; \mathrm{CH}=30 \mu \mathrm{g}$ chloramphenicol; $\mathrm{SP}=10 \mu \mathrm{g}$ sparfloxacin; $\mathrm{CPX}=10 \mu \mathrm{g}$ ciprofloxacin; $\mathrm{AM}=30 \mu \mathrm{g}$ Amoxacillin; $\mathrm{AU}=30 \mu \mathrm{g}$ Augmentin; $\mathrm{CN}=10 \mu \mathrm{g}$ Gentamycin; $\mathrm{PEF}=30 \mu \mathrm{g}$ perfloxacin; $\mathrm{OFX}=10 \mu \mathrm{g}$ tarivid; $\mathrm{S}=30 \mu \mathrm{g}$ streptomycin.

(cotrimoxazole), amoxicillin and streptomycin; $75 \%$ to ciprofloxacin (a quinolone mostly prescribed currently), tarivid and perfloxacin (also quinolones) etc. These findings validate the data from WILLEY et al. ${ }^{20}$. It also falls in line with the findings of SAHM et al. ${ }^{18}$ where $95.8 \%$ of E. coli isolated was resistant to ampicillin and $92.8 \%$ to trimethoprimsulfamethoxazole (drug of choice in United States). The $83.3 \%$ E. coli resistant to cotrimoxazole and amoxicillin is supported by the data from ODUYEBO et al..$^{15}$ where all E. coli showed resistance to amoxicillinclavulanic acid and $87.5 \%$ to cotrimoxazole and also in OLSON et al. ${ }^{16}$ in which a total of $80.1 \%$ E. coli tested was resistant to ampicillin.

All S. aureus isolates were resistant to Amoxicillin Clavulanate. In ONANUGA et al. ${ }^{17}$, all $S$. aureus tested were resistant to ampicillin. Similarly, Klebsiella species were all resistant to cotrimoxazole and augmentin while all $P$. aeruginosa were also resistant to cotrimoxazole, chloramphenicol and augmentin. High resistance of Klebsiella species to cotrimoxazole was observed by ODUYEBO et al. ${ }^{15}$ where it was $87.5 \%$ while that of $P$. aeruginosa to amoxicillin/clavulanate (Augumentin) and cotrimoxazole is supported by findings of AIYEGORO et al. ${ }^{1}$. Our findings and those of others seem to contradict the statements of BROOKS et al. ${ }^{3}$ who reported that excretion of high percentage of ampicillin and amoxicillin in urine as a basis for their preference in treatment of acute urinary tract infections. This contradiction might have resulted from abuse of these drugs in the environment leading to urinary pathogens becoming more resistant to them.

In conclusion, we observed high resistances of isolates to antibiotics which is consistent with the information in literature. Furthermore, test results with broad spectrum antibiotics showed that Gram-negative isolates are showing higher resistances than Gram-positives.

Some of the limitations of our study include the non-determination of the MICs of the tested antibiotics and the non- inclusion of control strains in the susceptibility studies because they were not available. 


\section{RESUMO}

\section{Perfil da frequência, análise urinária e suscetibilidade de patógenos causando infecções do trato urinário no estado de Enugu, Sudeste da Nigéria}

Objetivo: $\mathrm{O}$ estudo teve como objetivo determinar a frequência e agentes causadores das infecções do trato urinário (UTIs) em indivíduos com sintomas desta infecção no estado de Enugu, Sudeste da Nigéria e determinar a suscetibilidade antibiótica dos agentes microbianos isolados de cultura da urina. Métodos: O estudo envolveu 211 indivíduos (149 mulheres e 62 homens) clinicamente suspeitos para UTI. Amostras urinárias foram coletadas pelo método de meia corrente "clean catch" e testados por procedimentos standards. Suscetibilidade aos antibióticos dos patógenos isolados foi testada usando a técnica de Kirby-Bauer e de acordo com as diretrizes do "Clinical and Laboratory Standards Institute" (CLSI). Resultados: Microscopia das amostras de urina centrifugadas mostraram que 16 pacientes tinham piúria enquanto que 54 tinham células do pus. Cristais de oxalato de cálcio foram encontrados em 14 amostras. Análise de amostras da urina mostraram que 17 tinham proteína; sete eram positivas para nitrito e três tinham concentração de glicose de moderada para alta. Cinquenta e quatro amostras de urina $(36.2 \%$ de mulheres) e 12 ( $19.45 \%$ de homens) mostraram crescimento significante após cultura. Coloração pelo Gram e testes bioquímicos identificaram nove organismos diferentes com a Escherichia coli sendo a mais comum das espécies isoladas. Quarenta e três espécies selecionadas ao acaso foram testadas posteriormente para sua suscetibilidade contra um painel de antibióticos. Trinta amostras isoladas $(81.08 \%)$ foram resistentes a quatro ou mais antibióticos sendo que a maior resistência foi da $E$. coli (76.67\%). Todas as amostras Gram negativas isoladas foram resistentes a Ampicilox, Cefuroxime e Amoxicilina.

\section{ACKNOWLEDGEMENTS}

The authors wish to thank the authorities of the three centers where samples were collected for their interest in clinical research and their help during sample collection. We also wish to thank all the persons who gave consent and submitted their urine samples for this study.

\section{CONFLICT OF INTEREST}

Authors have no conflict of interest to declare.

\section{REFERENCES}

1. Aiyegoro OA, Igbinosa OO, Ogunmwonyi IN, Odjadjare EE, Igbinosa OE, Okoh AI. Incidence of urinary tract infection (UTI) among children and adolescents of Ile-Ife Nigeria. Afr J Microbiol Res. 2007;1:13-9.

2. Akoachere JF, Yvonne S, Akum NH, Seraphine EN. Etiologic profile and antimicrobial susceptibility of community-acquired urinary tract infection in two Cameroonian towns. BMC Res Notes. 2012;5:219.

3. Brooks GF, Carroll KC, Butel JS, Morse SA. In: Jawetz, Melnick, Adelberg's medical Microbiology. New York: McGraw Hill; 2007.

4. Cheesbrough, M. District laboratory practice in tropical countries. Part 2. $2^{\text {nd }}$ ed Cambridge: University Press; 2004. p. 105-14.
5. Chukwu BF, Okafor HU, Ikefuna AN. Asymptomatic bacteriuria in children with sickle cell anemia at the University of Nigeria teaching hospital, Enugu, South East, Nigeria. Ital J Pediatr., 2011;37:45.

6. Eyong ME, Ikepeme EE, Ekanem EE. Relationship between Schistosoma haematobium infection and urinary tract infection among children in South Eastern, Nigeria. Niger Postgrad Med J. 2008,15:89-93.

7. Gonzalez CM, Schaeffer AJ. Treatment of urinary tract infection: what's old, what's new, and what works. World J Urol. 1999;6:372-82.

8. Hooton TM, Scholes D, Hughes JP, Winter C, Roberts PL, Stapleton AE, et al. A prospective study of risk factors for symptomatic urinary tract infection in young women. N Engl J Med. 1996,335:468-74.

9. Karlowsky JA, Lagacé-Wiens PR, Simner PJ, DeCorby MR, Adam HJ, Walkty A, et al. Antimicrobial resistance in urinary tract pathogens in Canada from 2007 to 2009: CANWARD surveillance study. Antimicrob Agents Chemother. 2011;55:3169-75

10. Kwok W, Kwaadsteniet MC, Harmsen M, van Suijlekom-Smit LW, Schellevis FG, van der Wouden JC. Incidence rates and management of urinary tract infections among children in Dutch general practice: results from a nation-wide registration study. BMC Pediatr. 2006,6:10.

11. Laupland KB, Magshaw SM, Gregson DB, Kirkpatrick AW, Ross J, Church DL. Intensive care unit-acquired urinary tract infections in a regional critical care system. Crit Care. 2005;9:60-5.

12. Muvunyi CM, Masaisa F, Bayingana C, Mutesa L, Musemakweri A, Muhirwa G, et al. Decreased susceptibility to commonly used antimicrobial agents in bacterial pathogens isolated from urinary tract infections in Rwanda: need for new antimicrobial guidelines. Am J Trop Med Hyg. 2011;84:923-8.

13. National Committee for Clinical Laboratory Standards. Methods for disk susceptibility test for bacteria that grow aerobically. $7^{\text {th }} \mathrm{ed}$. Wayne: National Committee for Clinical Laboratory Standards. (NCCLS Document M2-A7).

14. Obiogbolu CH, Okonko IO, Anyamere CO, Adedeji AO, Akanbi AO, Ogun AA, et al. Incidence of Urinary Tract Infections (UTIs) among pregnant women in Akwa metropolis, Southeastern Nigeria. Sci Res Essays. 2009,4:820-4

15. Oduyebo OO, Daso MA, Uti RA, Ketiku KK. Prevalence of urinary tract infection in patients undergoing pelvic radiotherapy at a teaching hospital in Lagos, Nigeria. J Nigerian Infect Control Assoc. 2001,4:6-10.

16. Olson RP, Harrell LJ, Kaye KS. Antibiotic resistance in urinary isolates of Escherichia coli from college women with urinary tract infections. Antimicrob Agents Chemother. 2009,53:1285-6.

17. Onanuga A, Oyi AR, Olayinka BO, Onaolapo JA. Prevalence of community-associated multi-resistant Staphylococcus aureus among healthy women in Abuja, Nigeria. Afr J Biotech. 2005;4:942-5.

18. Sahm DF, Thornsberry C, Mayfield DC, Jones ME, Karlowsky JA. Multi-drug resistant urinary tract isolates of Escherichia coli: prevalence and patient demographics in the United States in 2000. Antimicrob Agents Chemother. 2001;45:1402-6.

19. The British Medical Association. Illustrated medical dictionary. London: Dorling Kindersley; 2002.

20. Willey JM, Sherwood LM, Woolverton JC. In: Prescott, Harley and Klein's Microbiology. $7^{\text {th }}$ ed. Boston: McGraw; 2008.

21. Zeighami H. Urinary tract infections in renal transplantation patient. Res J Biol Sci. 2008;3:1194-6.

Received: 16 January 2013

Accepted: 18 April 2013 